無触媒では $3.2 \%$ のビフェニルが生成するのみであるが，塩化 鉄(II) (10-3 当量)を用いるとビフェニル $38 \%, n$-ヘキシルベン ゼン $36 \% ， n$-ドデカン $11 \%$ が生成した。したがって第三級ア ルキル基をもつ Grignard 試薬のように立体勃果が大きい場合 には金属塩を還元する能力がなく活性中間体が生成し難いといえ る。しかしながら塩化アリルや塩化ベンジルをハロゲン化アル キルのかわりに用いるとカップリングの進み方が異なり12), Kharasch らが考えているような単純なラジカル機構では説明で きない点が多いので, 活性中間体に対しての詳しい検討が必要で ある。

\section{5 結 語}

Grignard 試薬に 金属塩を加えてハロゲン化アルキルのカップ リングを行なう方法として，従来は A， B 再反応を同時に行なう 操作が用いられていたため，その生成物から，全体の反応経過が 単純なラジカル機構で進むものと考えられていたようである。し

12）大部芳広, 松田 晶, 日本化学会中国四国大会(岡山市) 講演 (1967 年 10 月).
かしながら本研究の結果から，A，Bの反応は别々に考えねばな らないこと，とくにB反応が重要であることが明らかになり，ま たこれらを別々に行なうことによって微量の金属塩化物がハロゲ ン化アルキルのカップリングに顕著な触媒効果をおよぼし，しか も金属塩の種類によって触媒作用が異なることがわかった。本研 究においては飽和のアルキル基をもつ Grignard 試薬およびハロ ゲン化アルキルの組み合わせを用いているため，現在の段階では 合成方法としての利点はないが，ハロゲンの種類を变えることに より，あるいは反応性の大きいハロゲン化アリル，ハロゲン化ベ ンジルあるいはハロゲン化アセチレンなどを用いれば，金属塩の 種類および量を变えることにより選択的にカップリング反応を進 めうる可能性があり，現在この点について実験を行なっている。 つぎに Grignard 試薬と金属塩から生成し，触媒として働いてい る活性な中間体はエーテル溶液中においてかなり安定に存在して いることがわかったので，低温において生成しえると考えられる 鉄，銅，コバルト，ニッケルなどのアルキル金属化合物とどのよ うな関連があるかについて研究を進める予定である。

(1967 年 4 月, 日本化学会第 20 年会講演)

\title{
パラジゥムー岩素触媒によるアニリンの液相水素化 $*_{1}, *_{2}$
}

\author{
（昭和 42 年, 9 月 7 日 受理 )
}

池舘 和 江 ${ }^{* 3} \cdot$ 鈴 木 邁*4 鈴 木 貞 雄*3

\begin{abstract}
パラジウムー炭素触媒を用いてアニリンの水素化機構を検討した。アニリンは直接シクロヘキシルアミンに水素化される一方,

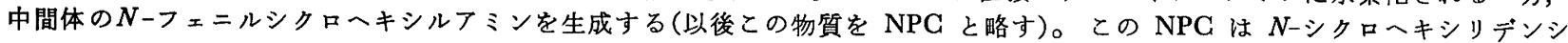
クロヘキシルフミンを経てジシクロヘキシルアミンに水素化される。また水素化中に NPG がてニリンから生成する際，副生した 酢酸アンモニウムと反応し，シクロへキシルフミンを生成する。NPC のシクロへキシルフミンへの分解は，NPG に酢酸了ンモ ニウムを添加して水素化反応を行なうことにより確認された。アニリンから直接水素化によりシクロへキシルアミンを生成する速 度, および NPC 分解速度がシクロへキシルアミンへの選択率を支配する重要な因子になっているととが認められた。酢酸フンモ ニウムをアニリン水素化のはじめに加文，NPG の生成が抑制されるか否かを検討した。酢酸了ンモ二ウムは水素化活性を低下さ せなかったが，NPC の生成も抑制しなかった。しかし NPG の分解を促し，シクロへキシルアミンへの選択率を上げることがで きた。考察した反応機構が他の触媒にも適用できるかどうかを検討するため, Adams 酸化白金触媒と, $7: 3$ 口ジウムー白金触媒 について検討を行なった。本実験条件下におけるジシクロへキシルフミン生成の主経路は，NPCを経るむのであることが確認さ れた。
\end{abstract}

\section{1 緒言}

アニリンの水素化においては，しばしば低温においても副生成 物のシシクロヘキシルアミンが生成する。また，触媒によってシ クロヘキシルアミンへの選択率が大きく異なっている。したがっ て，アニリン水素化の選択性を支配する因子を考察するために， その水素化機構を究明することは重要である。アニリンの水素化 機構に関しては, Jungers らうがニッケル触媒を用い液相 $200^{\circ} \mathrm{C}$

*1 との報文を“アニリンの夜相水素化(第 2 報)”とする.

*2 前報 (第 1 報), 池舘和江, 鈴木 薄, 鈴木貞雄, 日化, 88, 972(1967).

*3 Kazue IKedATE, Sadao Suzuki 東京工業大学資源化 学研究所, 東京都目黒区大阔山

*4 Tsutomu SUZukI 千葉大学工学部, 千葉市弥生町

1) J. C. Jungers, G, Debus, Chem. Abstr., 48, 6975(1954).
ぐらいで検討を行なっている。さらに近年, Moravec ら²や, Hagihara ら³が高温気相で, Greenfield ${ }^{4)}$ が液相 $120 \sim 145^{\circ} \mathrm{G} て ゙$ 㭘討を行なっているが，まだ定説になるにいたっていない，また 低温液相での研究は行なわれていない。そこで反応機構を明らか にするため，前報らに引きつづき常圧常温付近におけるアニリン の液相水素化を，パラジウムー炭素を触媒として検討した。はじ めに前報に報告した中間体を単離し，検討した。その結果，低温 液相反応においてジシクロヘキシルアミン生成の主経路は NPC

2) P. Moravec, P. Schreider, M. Kraus, Collection Czechoslov. Chem. Commun., 30, 2908(1965).

3) H. Hagihara, E. Echigoya, Bull. Chem. Soc. Japan, 38, 2094 (1965).

4) H. Greenfield, J. Org. Chem., 29, 3082(1964).

5）前報(第 1 報)，池舘和江，鈴木 造，鈴木貞雄，日化， 88, 972(1967). 
を中間体として進むものであることが傕認された。一方 NPGを 中間体としてシクロヘキシルアミンが生成する反応経路の存在が 明らかになった。この経路はまったく新しく見いだされたもので ある。アニリンが水素化中に脱アンモニアを起こして NPC を生 成し，ふたたびアンモニアを取り込んでシクロヘキシルアミンを 生成することは興味ある事実である。

さらに，考察した反応機構が他の触媒についても妥当性がある かどうかを検討するため, 酸化白金触媒, および $7: 3$ ロジウムー 白金触媒についても検討を行なった。

\section{2 実験}

\section{1 装置および操作}

前報らりに報告したものと同様なので省略する。

\section{2 触 媒}

パラジウムー炭系触媒は前報と同じ，酸化白金は Adams 型の ものを使用。7:3 ロジゥム-白金触媒は西村6)の報告に基づいて 合成して使用した。

\section{3 分 析}

ガスクロマトグラフを用いた。検出には水素炎と熱伝導度の両 方を用いた。他の条件は前報と同様である。

\section{2 中間体の単離および検討}

$5 \%$ パラジウムー炭素 $2 \mathrm{~g}$ を触媒とし, 酶酸 $100 \mathrm{ml}$ を溶媒と

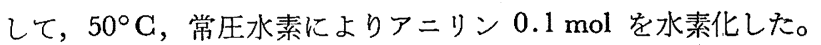
(以下の実験も同様な条件のもとで行なった)。中間体濃度の最高 になるあたりで反応をとめ，触媒を分離し，反応液にアニリンと 等モル以上になるように濃塩酸を加えたのち, 溶媒の酶酸を減圧 蒸留によって除き，残留液を氷冷すると結晶化した。この結晶を 酢酸を少量加えた水溶液で 3 回再結晶し, 白色針状結晶を得た。 これを真空デシケーター中で 3 日間乾燥後, 赤外吸収スペクトル, 元素分析，分子量測定を行なって検討した。最後に合成品により ガスクロマトグラフで同定を行なった。

\section{3 結果および考察}

\section{1 中間体としての NPG の確認}

反応液から塩酸塩の結晶として単離した中間体の赤外吸収スペ クトルは, ベンゼン核の面外振動, ベンゼン一置換体の特性吸収 を明膫に示した。また $\mathrm{CH}_{2}$, およびシクロヘキサン環の特性吸 収を示し，ベンゼン一置換体でシクロヘキサン環をもつ NPC で あることを示唆した。元素分析の結果はつぎのとおりであった。

$$
\text { 分析值 C } 67.83 \%, \mathrm{H} 8.25 \%, \mathrm{~N} 6.71 \%
$$

$\mathrm{C}_{12} \mathrm{H}_{18} \mathrm{NGl}$ としての

$$
\text { 計算值 G } 68.07 \%, \mathrm{H} 8.57 \%, \mathrm{~N} 6.62 \%
$$

$\pm 0.4 \%$ 以内で $\mathrm{NPC} \cdot \mathrm{HCl}$ の計算值と一致した。塭酸塩の結晶 は白色針状結晶で融点は $204^{\circ} \mathrm{C}$ で交献值》と一致した。合成品 によるガスクロマトグラフは保持時間の一致を示した。以上のこ とから，シクロヘキシルアミンおよびジシクロヘキシルアミンに 転化する一つの中間体として NPG が存在することを 確認した。

\subsection{NPG の経時変化}

アニリンの水素化中における NPG の経㭙変化を定量的に追跡 するため，アニリン $0.08 \mathrm{~mol}$ を酢酸 $100 \mathrm{ml}$ に溶解して実驗を

6) S. Nishimura, Bull. Chem. Soc. Japan, 34, 1544(1961).

7) A. Skita, F. Keil, Ber., 61, 1682(1928).
行なった。結果が図1である。NPG は明らかにシシシクロヘキシ ルテくンの中間体になっている。また， NPG 減少時からシクロ ヘキシルアミンの生成量が急速に立ち上り，このことは NPCを 経てシクロヘキシルアミンの生成する反応経路が存在することを 示している。 NPG がシシシクロヘキシルアミンへの中間体である ことを認めている報交1 3)はあるが，NPG を経てシクロヘキシ ルアミンが生成するという経路はまったく新しく得られた知見で ある。アニリンは水素化中に脱アンモニアを起こして NPG を生 じ,ささらふたたびアンモニアを取り込んで分解し, シクロへキ シルアミンを生ずるという複雑な経路を経て反応が進行すること が明らかになった。生成率と転化率をつぎのように定義する。

$$
\frac{\text { 生成物浱度 }(\mathrm{mol} / 100 \mathrm{ml})}{\text { 原料了ニリン濃度 }(\mathrm{mol} / 100 \mathrm{ml})} \times 100=\text { 生成率 }(\%)
$$

$\mathrm{NPG}$ とジシクロヘキシルアミンの場合は

$$
\begin{aligned}
& \frac{2 \times \text { 生成物濃度 }(\mathrm{mol} / 100 \mathrm{ml})}{\text { 原料アニリン濃度 }(\mathrm{mol} / 100 \mathrm{ml})} \times 100=\text { 転化率 }(\%) \\
& \text { シクロヘキシルア }
\end{aligned}
$$

生成物濃度 $(\mathrm{mol} / 100 \mathrm{~m} l)$

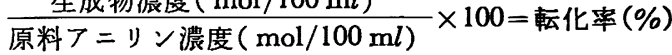

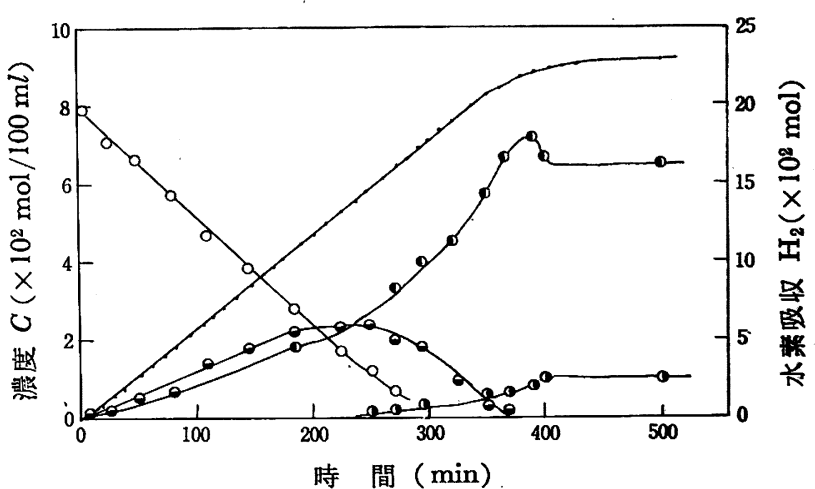

$$
\begin{array}{ll}
\text { O: アニリン, } & \ominus: \mathrm{NPG} \\
\text { D: シクロヘキシルフミン, } & \bullet: \text { 水素吸収 } \\
\text { (): ジシクロへキシルフミン } &
\end{array}
$$

図 1 フニリンの水素化 $\left(50^{\circ} \mathrm{C}\right)$

NPG はこの実験の最高生成時において，原料の $30 \%$ 量生成 した。これはアニリンの転化率になおすと $60 \%$ に相当する。す し生成 NPG のすべてがジシクロヘキシルアミンになるとするな ら，最終時において $30 \%$ のジシクロヘキシルアミンが生成しな 、ければならない。しかし, 最終時においてジシクロヘキシルアミ ンは 15\% しか生成しない。これは転化率になおすと 30\% であ る。したがって転化率の差 30\% は, シクロヘキシルアミンを生成 しているとみなされる。シクロヘキシルアミンは最高時において 80\% 生成したが, 最終時においては 70\%となった。以上のこと から，生成シクロヘキシルアミンの少なくとも約 40\% は NPG を経て水素化されたものであると考えられる。したがって新しく 見いだされた反応経路は，パラジウムー炭素触媒によるアニリン の水素化において重要なものであると考えられる。因1から NPG は反応初期においてアニリン濃度に 0 次で生成することが認めら れる。NPG 生成の活性化エネルギーを求めると $12.5 \mathrm{kcal} / \mathrm{mol}$ で(図 2)，ほとんどアニリンの全反応の活性化エネルギーに等し かった。したがって NPG 生成の律速段階は,アニリンの水秦化 段階にあると考えられる。 


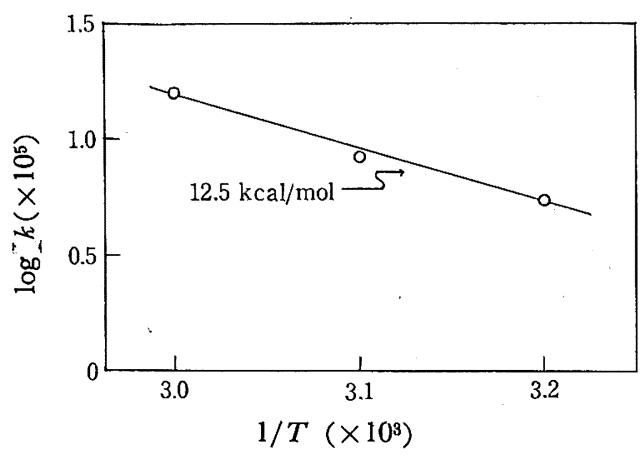

図 2 NPG 生成の活性化エネルギー

\subsection{NPG の水素化}

NPG の直接水素化分解によってシクロヘキシルアミンが生成 するか否かを検討するために，NPG のみの水素化を行なった。 NPC $0.03 \mathrm{~mol}$ を酶酸 $100 \mathrm{ml}$ に溶解し, 上述の実験条件で反応 させた。結果が図 3 である。NPC のほとんどが定量的にシジク ロヘキシルアミンに転化し，この物質の直接分解によるシクロヘ キシルアそンの生成はほとえど認められなかった。ジシクロへキ シルアミンの生成曲線は明瞭な变曲点を示し, 逐次反応によって 生成することが明らかとなった。罒中点線で示したものは，NPG の初濃度から残存 NPG と生成シジクヘキシルアミンの量を差 し引いた值である。ガスクロマトグラフの同定によりこの物質が

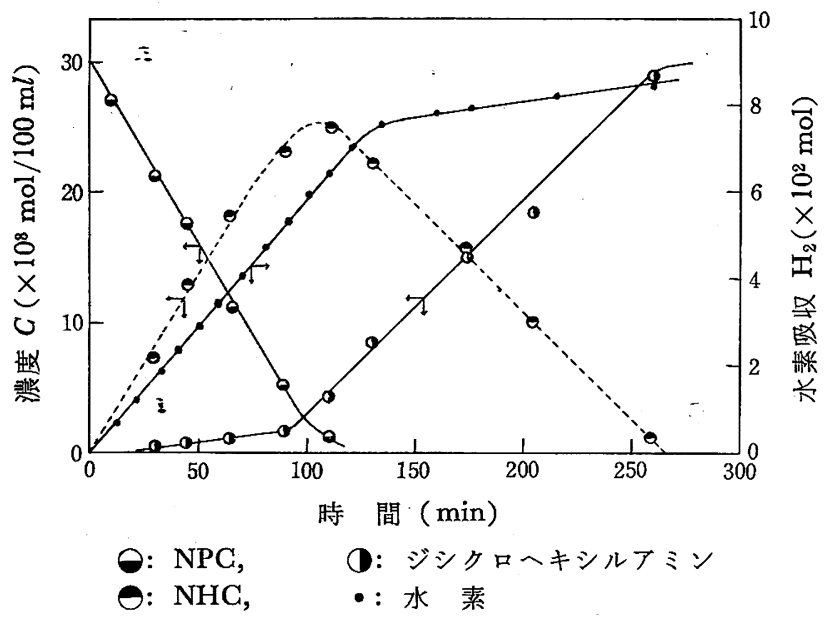

図 3 NPG の水素化

$N$-シクロヘキシリデンシクロヘキシルアミンであることを認めた (以後この物質を NHC と略す)。一方この中間体濃度が減少し, シシクロヘキシルアミンの生成が立ち上ってきたととろの水素吸 収速度とシシクロヘキシルアミン生成速度との比をとると $1: 1$ になる。このことは NHC が NPC からシシクロヘキシルアミ ンを生成する中間体となっていることを支持する。Hagihara ら は NPC を通る経路と, NHC を通る経路を別々に考えているが， 本実験では，NPG が水素化されて NHG を生じ，それがさらに 水素化されて ジシクロヘキシルアミンを生ずるものと考えられ る。四から明らかなように NPG 注料浱度に0 次で水素化され るが，さらに NPG の濃度を変光て，0.03〜0.06 mol $/ 100 \mathrm{ml}$ の 範囲で反応速度はほとんど等しく0次であることが確認された。 実験 3.2 では NPG のシクロヘキシルアランへの分解が認めら
れたが，この実験ではほとえど分解が起こらなかった。そこでさ きの実験の場合には，アニリンから NPG が生成する際に生じた アンモニアが存在することに注目し，アンモニアと溶媒の酶酸が 反応して生ずる酢酸アンモニウムを加えて，NPG の水素化を試 みた。

\section{4 酢酸アンモニウムを添加した場合の NPG の水素化}

NPC $0.02 \mathrm{~mol}$ に酶酸アンモニウム $0.03 \mathrm{~mol}$ 它加え, 溶媒に 酢酸 $100 \mathrm{ml}$ を用いて上と同じ条件のもとに実験を行なった。結 果を図 4 に示す。この場合はシクロヘキシルアミンが約 $50 \%$ 生 成し, 酢酸アンモニウムの存在下に NPG は明らかに分解を起こ してシクロヘキシルアミンを生成した。初期シクロヘキシルアミ ン生成曲線は明らかに变曲点を示しており，NHG を中間体とす るような逐次反応によって進行していることを示している。この 実験において，反応中にイミンと考えられる保持時間の短い物質 が，ガスクロマトグラフによって検出された。反応速度は無添加 の場合とほとえど等しく，酢酸アンモニウムによる水素化活性の 抑制はほとえど見られなかった。

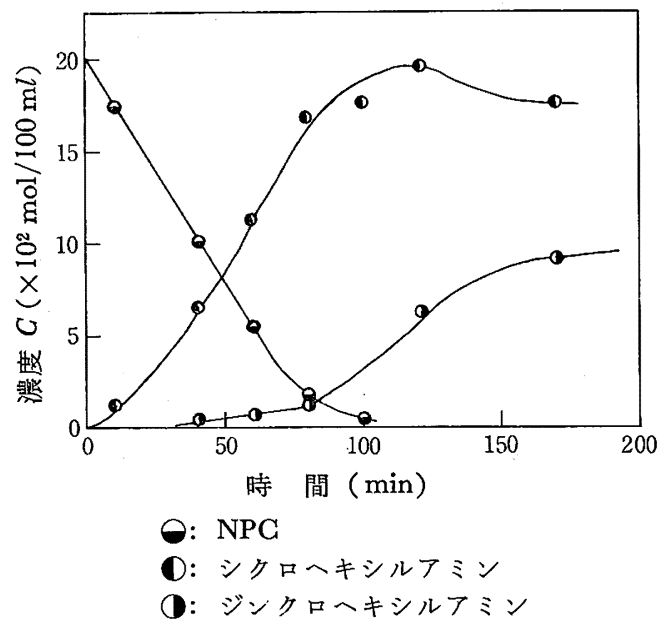

図 4 酶酸アンモニウム存在下の NPG の水素化

\section{5 酢酸アンモニウムの濃度変化}

酢酸アンモニウムの添加量を変えた場合について検討した。結 果をさきの実験の結果とともに表 1 にまとめた。速度変化はみら れず酶酸アンモニウムの浱度に0次であった。このことは酢酸ア ンモニウムが水素化の活性点を被毒しないことを意味している。

NPG を加える前に酶酸アンモニウムを反応系に入れ，さきに 触媒上へ吸着させた場合の速度および生成物変化について検討し てみたが，いくぶえの速度低下が起こる程度で大きな変化はなか った。この速度の低下は触媒上のきわめて活性の高い点に，さき に添加された酰酸アンモニウムが一部不可逆吸着してしまうこと によると考える。全般的に見て䣷酸アンモニウムを添加した場合 のシクロヘキシルアミンへの転化率は 40～50\%である。すなわ ち原料の約 $1 / 2$ が分解を起こしている。このことは，NPGの分 解速度とシショロヘキシルアミンへ直接水素化される速度が注ぼ 等しいことを示唆している。

\section{6 反応機構}

以上の結果を総合して，アニリンの水素化機構を考察すると図 6 のようになる。

はじめにアニリン 1 分子に水素 1 分子が入ってジェン化合物が 


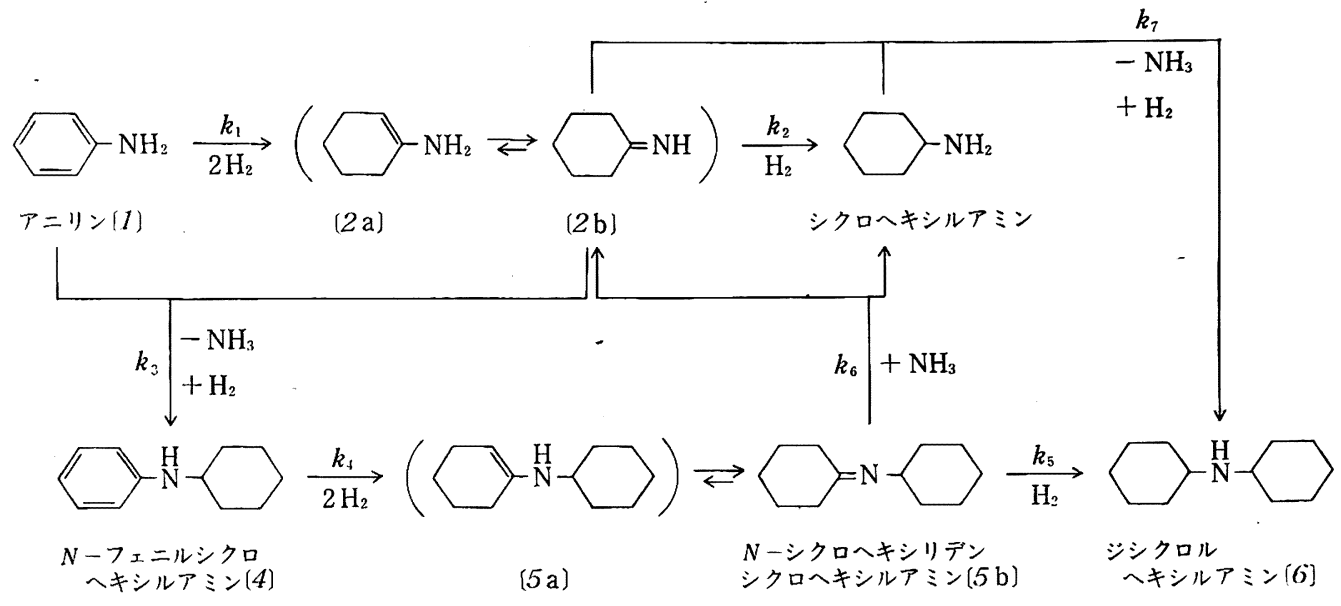

（）をつけた物質は確認してないものである.

四 6 フ

表 1 NPG の水素化

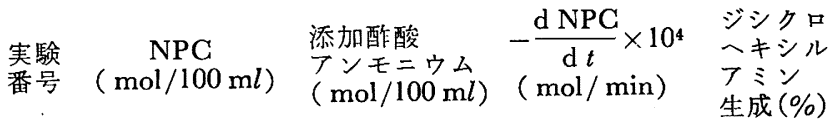

$\begin{array}{lllll}1 & 0.03 & - & 2.76 & 90 \\ 2 & 0.02 & 0.02 & 2.86 & 45 \\ 3 & 0.02 & 0.034 & 2.93 & 40 \\ 4^{a)} & 0.02 & 0.02 & 2.17 & 50 \\ 5^{a)} & 0.02 & 0.034 & 2.30 & 50\end{array}$

注 $a$ ）触媒にさきに酢酸丁ンモニウムを吸着させた場合.

生成すると考えられるが，この物質は非常に不安定であり，生成 するとすぐに水素化されてエナミン〔2a]を生ずると考えられる。 〔2 a 〕はアミンが酶酸塩を形成し，正に帯電しているために，ま た窒素の電気陰性度が炭素より大きいために 1-位の $\pi$ 電子を引 きやすく，ただちに互変異性してイミン〔2 b]を生成すると推定 される。イミンの生成に関しては Jungers' ${ }^{1)} や$ Greenfield4) も水 の存在下におけるアニリンの水素化で, シクロヘキサノンが生成 することから考察している。また，パラジウムー炭素を触媒とし てフェノールの水素化を行なった場合，シクロヘキサノールへの 中間体としてシクロヘキサノンが定量的に生成する゙ことからも 類推される。Greenfield はシジクロヘキシルアミンの生成に関し て，イミンとシクロヘキシルアミンの反応を考えているが，本実 験では図1からも明らかなように, 反応初期ではシクロヘキシル アミンの存在にもかかわらず，ジシクロヘキシルアミンはほとん ど生成しなかった。このことは，アニリン存在中は[ $2 \mathrm{~b}]$ とアニ リンの反応がおもに起こり，シクロヘキシルアミンと[2 b]との 反応は起こっていないことを示している。水素化反応がアニリン 濃度に0 次で進行することから,アニリンの吸着は強く,触媒上で 浱度が高くなっており，生成イミンがただちに水素化されるもの 以外はアニリンと反応して，NPG を生ずるものと考えられる。 アニリン減少モル速度と NPG 生成速度との比をとると $3: 1$ K なる。このことはアニリン $3 \mathrm{~mol}$ が反応して, NPG $1 \mathrm{~mol}$ とシ クロヘキシルアミン $1 \mathrm{~mol}$ を生ずることを意味している。さら にアニリン減少速度と水素吸収モル速度との此をとると $1: 2$ K

8) 松本陸实, 久保田秀亥, 鈴木 邁, 鈴木貞雄, 日本化学 会第 19 年会講演予稿集 $\mathbb{I I},(1965)$ p. 168.
なる。このことは $3 \mathrm{~mol}$ のアニリンに対し $6 \mathrm{~mol}$ の水素を吸収 することで，上の関係を支持する。したがってパラジウムー炭素 上で $50^{\circ} \mathrm{G}$ ぐらいの反応温度では $k_{2}$ と $k_{3}$ がほぼ同程度の大き さであると推定される。アニリンが NPG を中間体としてシジク ロヘキシルアミンに水素化される経路が存在することは, Junger ら1)や Moravec らももニッケル触媒上で行なった研究により認め ている。本実験においても，シジクロキシルアミン生成の主経 路は NPG を経るものであることが認められた。

NPC にアンモニアがふたたび入る段階に関しては，NPG と酢 酸アンモニウムの反応で，シクロヘキシルアミンが逐次的に生成 することから NHC に酢酸アンニウムが反応し，イミンとシク ロヘキシルアミンを生成すると考光る。眓 1 に示されているよう に，アニリン水素化の反応後期においてシクロヘキシルアミン生 成量が極大を示したのち，少し減少してから一定值になる。この ことはアニリンや NPC がなくなり，触媒上におけるシクロへ キシルアミンの濃度が高くなうた場合には, イミンとシクロヘシ キルアミンが反応し，ジシクロヘキシルアミンを生成することを 示唆する。この反応経路は Greenfield4も考察を行なっているが 本実験においてはこの反応の 中間体として NHG が存在するか 否かは明らかでない。なお反応の後期において，実験 3.4 で認 められたと同様のイミンと考えられる物質が検出された。

またシクロヘキシルアミン生成量が最終的に一定值を示すこと は，この条件下でシクロヘキシルアミンの 2 分子縮合によるジシ クロヘキシルアミンの生成がないことを示している。

\section{7 アニリンの水素化におよぼす酢酸アンモニウムの添加効} 果

アニリンの水素化のはじめに酶酸アンモニウムを加え,NPC の 生成が抑制されるか否かを検討した。アニリン $0.08 \mathrm{~mol}$ に酶酸 アンモニウム $0.03 \mathrm{~mol}$ を加え, 酢酸 $100 \mathrm{ml}$ に溶解して実験を 行なった。これを看添加の場合とともに表 2 に記した。

酶酸アンモニウムの添加はアニリンの水素化速度を低下させな かったが，NPG の生成速度をも抑制しなかった。そして無添加 の場合とほぼ同量の約 20\%の NPG を生成した。しかし酶酸ア ンモニウムの添加は, NPG の分解を促し, シクロヘキシルアミ ンへの選択率を上げた。このようにパラジウム触媒の場合、酷酸 アンモニウムの添加は触媒の水素化活性を低下させずにシクロヘ 
表 2 酢酸アンモニウムのアニリン水素化に打よぼす影響

\begin{tabular}{|c|c|c|c|c|c|c|c|c|}
\hline $\begin{array}{l}\text { 実験 } \\
\text { 番号 }\end{array}$ & $\begin{array}{l}\text { 酢酸フンモニ } \\
\text { ウム添加量 } \\
(\mathrm{mol} / 100 \mathrm{ml})\end{array}$ & $\begin{array}{l}\frac{\mathrm{d} \mathrm{H}}{\mathrm{d} t} \times 10^{4} \\
(\mathrm{~mol} / \mathrm{min})\end{array}$ & $\begin{array}{l}\frac{\mathrm{d} \mathrm{A}}{\mathrm{d} t} \times 10^{4} \\
(\mathrm{~mol} / \mathrm{min})\end{array}$ & $\begin{array}{l}\frac{\mathrm{d} \mathrm{NPG}}{\mathrm{d} t} \times 10^{4} \\
(\mathrm{~mol} / \mathrm{min})\end{array}$ & $\begin{array}{l}\frac{\mathrm{d} \mathrm{C}}{\mathrm{d} t} \times 10^{4} \\
(\mathrm{~mol} / \mathrm{min})\end{array}$ & $\begin{array}{l}\text { NPG 最高 } \\
\text { 生成祭 } \\
(\%)\end{array}$ & $\begin{array}{c}\mathrm{D} \text { の最終 } \\
\text { 生成率 } \\
(\%)\end{array}$ & $\begin{array}{c}\mathrm{G} \text { の最終 } \\
\text { 生成率 } \\
(\%)\end{array}$ \\
\hline 1 & - & 9.3 & 4.7 & 1.67 & 1.43 & 23 & 17 & 62 \\
\hline 2 & 0.03 & 9.5 & 4.5 & 1.60 & 1.60 & 21 & 10 & 75 \\
\hline
\end{tabular}

注 $\mathrm{A}:$ ア アニリン, $\mathrm{G}$ : シクロヘキシルアミン, $\mathrm{D}:$ ジシクロヘキシルアミン.

触媒: $5 \% \mathrm{~Pb}-\mathrm{C} 2 \mathrm{~g}$, 反応温度: $60^{\circ} \mathrm{C}$, フニリン初濃度: $0.08 \mathrm{~mol} / 100 \mathrm{ml}$.

キシルアミンへの選択率を上げることができた。さらに従来アン モニアの添加は, 脱アンモニアを起こしてシシクロヘキシルアミ ンを生成する経路を抑制すると考えられてきたが，本実験条件下 では脱アンモニアの段階をおさえるのではなく，NPG のシクロ ヘキシルアミンへの分解を促すことにより，選択率を上昇させる ことが明らかになった。

\section{8 他の触媒上における水素化}

考察した反态機構が他の触媒の場合も適合できるか否かを検討 するために，Adams 型の酸化白金と，7:3 ロジウム-白金触媒 について実験を行なった。前者は酢酸溶媒中で容易に反応が進行 し，ジシクロヘキシルアミンを相当量生ずると報告9されれいる のでシシクロヘキシルアミン生成経路を確認するために，後者は 比較的選択性よくシクロヘキシルアミンを生成すると報告9 され ているので選択性を支配する因子を検討するために行なった。結 果が図 6 と図7である。酸化白金の場合もシシクロヘキシルアミ ンは，NPG を中間体として生成することが示された。この水素 化の場合，パラジウムやロジウムー白金を用いた場合と異なって アニリンの水素化と NPG の水素化が平行して起こった。これは

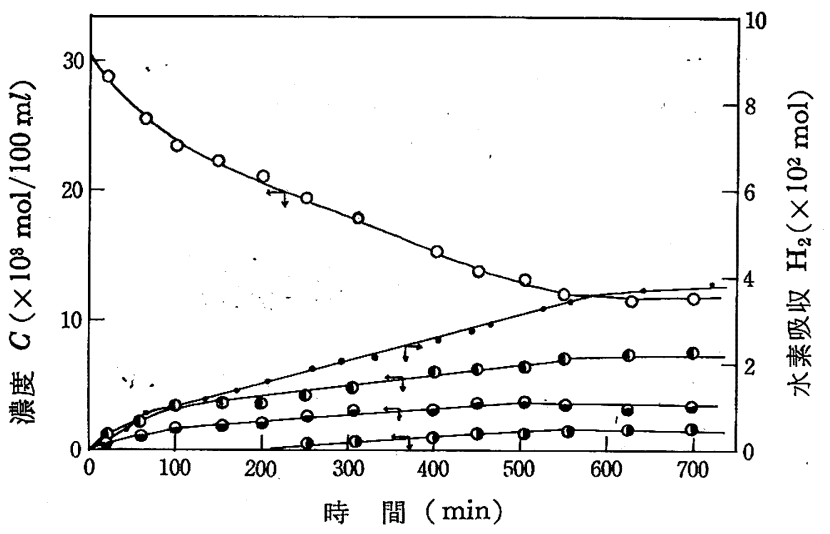

符号注図 1 と同じ.

図 6 Adams 型酸化白金触媒によるアニリンの水素化

触媒上へのアニリンと NPG の吸着力がほぼ等しいためであると 考えられる。酸化白金は 600 分ぐらいでほとんど活性が停止し てしまい， NPG からシクロヘキシルアミンへの分解が起こるか 否かについては明らかなことがいえない。7:3 ロジウムー白金触 媒による水素化は，パラジウム一炭素触媒の場合と同様，NPG を 経てシシクロヘキシルア々ンが生成することが明膫に示された。 反応初期にシシクロヘキシルアミンが生成しないことは，やはり イ乏ンとシクロヘキシルアミンとの反応は起こっていないとみな

9) S. Nishimura, H. Taguch, Bull. Chem. Soc. Japan, 34, 873(1963),
される。ほたこの場合アニリンと NPG の水素化は並発してい ない。最終的にシクロヘキシルアミンの $11 \%$ ぐらいは NPGを 経て水素化されたものであり, 新しく見いだされた反忘経路はこ の触媒の場合も無視しえないものである。

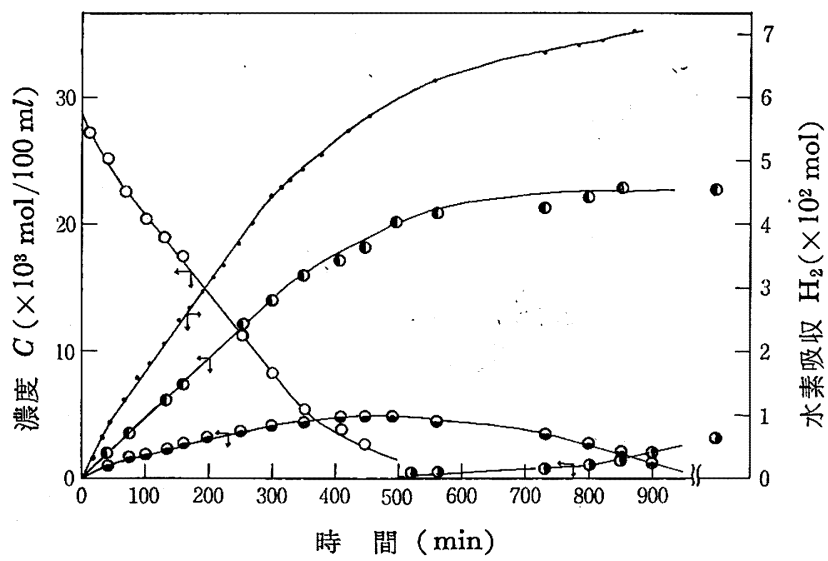

符号は図 1 と同じ。

図 $77: 3$ ロジウムー白金触媒によるアニリンの水素化

アニリンの水素化に括いてニッケル触媒を用いた気相 ${ }^{2)}$, 液相 ${ }^{1}$ における場合も NPG が生成し，これがジシクロヘキシルアミン への中間体となっていることを報告している。また，本研究にお けるパラジウム，白金，口ジウム白金の場合も同様であった。 したがって，シクロヘキシルアミン 2 分子から脱アンモニアを起 こしてシジクロヘキシルアミンを生ずるような高温水素化におけ る場合3を除いて，シシクロヘキシルアミン生成の主経路は NPG を経るものであると考える。

\section{9 三つの触媒に関する比較}

使用した三つの触媒について，活性および選択性を比較した。 結果をまとめたものが表 3 である。触煤は含有金属量として 0.1 $\mathrm{g}$ に統一した。全体の反応速度はパラジウムがロジウム白金の場 合の 2 倍, 酸化白金の 3〜4 倍であった。したがって活性は, $\mathrm{Pb}>\mathrm{Rh}-\mathrm{Pt}>\mathrm{Pt}$ の順で, $\mathrm{g}$ あたりの活性はパラジウムがもっとも

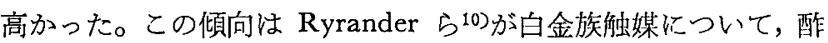
酸溶媒を用いて行なった実験の結果と一致し，パラジウムはアニ リンの水素化に対し，酢酸溶媒を用いた場合高い活性を持つこと が認められた。シクロヘキシルアミンへの選択性は, $\mathrm{Rh}-\mathrm{Pt}>\mathrm{Pd}>$ Pt で Rh-Pt がもっともよかった。この傾向はシクロヘキシルア ミン生成速度の傾向と一致し，イミンのシクロヘキシルアミンヘ の水素化速度 $\left(k_{2}\right)$ が選択率を支配する重要な因子になっている ことを示している。 $k_{2}$ は触媒の性質によっで巽なり, 蚛媒による 選択性の違い穵生じさせると考えられる。

10) P. N. Rylander, D. R. Steele, Engelhard Ind., Tech. Bull., 3, 19(1962). 


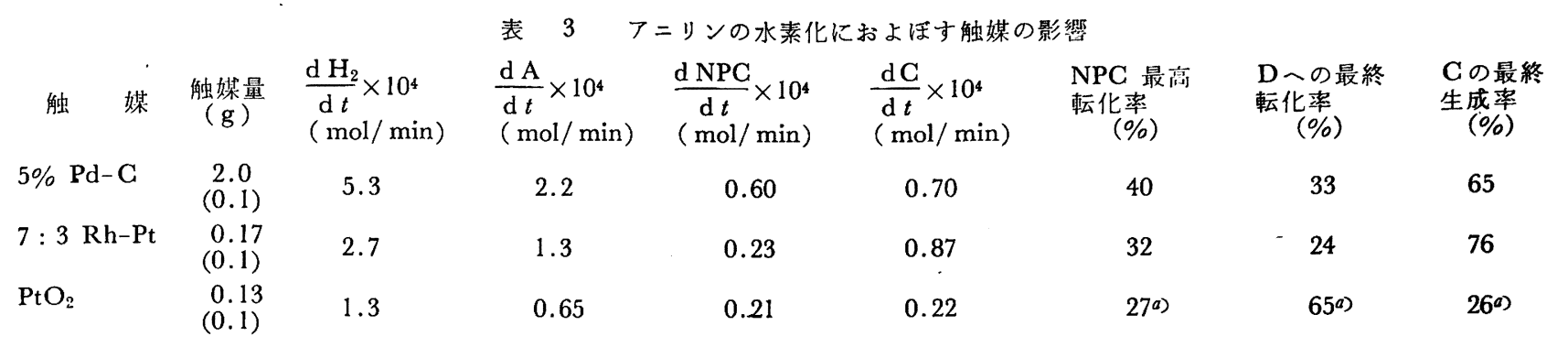

注 a） 700 分の生成率.

（）中の数字は金属含量. 反応温度： $50^{\circ} \mathrm{C}$, フニリン初濃度： $0.03 \mathrm{~mol} / 100 \mathrm{ml}$. 速度は定常活性になったところからとった.

また，パラジウムやロジウムー白金の場合に 認められたように NPG の分解速度 $\left(k_{6}\right)$ も選択率を支配するもう一つの因子になっ ていると考えられる。
元素分析をして下さった神原研究室の斎藤豊治技官に感謝致し ます。

（1967 年 4 月，日本化学会第 20 年会発表）

\section{過酸化ニッケルとフェノチアジン類との反応*,*2}

(昭和 42 年 10 月 18 日受理)

杉田実男·辻野陽一*3

ニッケル塩をアルカリ性で次亜塩素酸ナトリウムで酸化すると過酸化ニッケルが得られる。著者はとの過酸化二ッヶルを有譏反 応における固体酸化剂としての用途を開発するため研究を行なってきたが，本報ではフェノチフジン類との反応結果について報告 する。

フェノチアジンと過酸化ニッケルとを反応させるとフェノチフジンの重合体が得られる。このとき中間体としての二量体を単離 し，てのものは 3,10'-ビフェノチアジンであることを明らかにした。2-および 4-クロルフェノチアジンも同じように反応し，そ れぞれの重合体を生成する。

10-メチルフェノチフジンと過酸化ニッケルとの反応は，低温では進行せず，温度を上げると 5-オキシドおよび 5, 5-ジオキシ ドと少量のフェノチアゾンを与える。2-クロルー10-メチルフェノチアジンも同じように三者を与えるが，4-クロルー10-メチルフェ ノチフジンのときにはジオキシドの生成を認めず，オキシドおよびクロルーフェノチアゾンのみを生成する。

これらの生成物から反応経路について考察を加えた。

\section{1 緒言}

過酸化ニッケルはニッケル塩をアルカリ性次亜塩素酸ナトリウ ムで酸化してできる黑色の非晶形粉末で，溶媒に不溶の特異性の ある固体酸化剂である。この酸化剂の化学的な性状を知るために, 種々の化合物について酸化反応を試み，その生成物からこの酸化 剂の反応性を検討してきた。本報ではフェノチアジン類について 過酸化ニッケルを用いて酸化反応を試みた結果について 報告す る。

フェノチアジン類は古くから染料の中間体として，また最近で は医薬品の中間体として興味の対象となり，その酸化郕に対する 挙動については多大の注目が払われてきた。Pesci1ははフェノア シンを沸騰ベンゼン中で酸化水銀（II）を用いて酸化し，10,10'ービ フェノチアジンを得ている。また，フェノチアジン類を水酸基溶 媒中で過酸化水素水で酸化して5-オキシド2)を，酶酸中の過酸化

*1この報交を“過酸化ニッケルによる酸化反応の研究(第 9 報) ”とする。

*2 前報(第 8 報)，杉田実男，日化，88，1237(1967).

*3 Jitsuo Sugrta, Youichi Tsujino 塩野義製薬株式会社 研究所, 大阪市福島区蕗洲上通

1) L. Pesci, Gazz. Chim. Ital., 46, 103(1916).

2) A. C. Schmalz, J. Am. Chem. Soc., 76, 5455(1954).
水素酸化では 5,5-ジオキシドタを，そして酢酸中での重クロム酸 カリウム4)あるいは塩化鉄 (III) $)^{5}$ 酸化では 3- $\dot{H}$-フェノチアジン3-オン(フェノチアゾン)を生成することが知られている。

著者はフェノチアジン，そのクロル誘導体および 10-位のメチ ル置換体について，過酸化ニッケルを用いて反応を行ない，その 生成物の確認を行なった。また，これらの結果と第 5 報6)のカル バゾール類, 第 7 報7) のジフェニルアミンおよよび第 8 報8)のイ オウ化合物との反応の結果も考慮して,フェノチアジン類に対す る過酸化ニッケルによる酸化反応について考察を加えた。

\section{2 結果}

\section{1 フェノチアジン類と過酸化ニッケルとの反応}

2.1 .1 フェノチアジン〔1]と過酸化ニッケルとの反応:[1]の ベンゼン溶液に過酸化ニッケルの 1.5 モル比を加え, $30^{\circ} \mathrm{G}$ で

3) V. A. Skorodumov, Z. Org. Khim., 1, 202(1965).

4) C. Bodea et al., Ann., 614, 17(1958); 631, 194(1960). Z. Obshch. Khim., 30, 1131(1960).

5) C. Bodea et al., Acad. Rep. Populare Romine. Filiale Cluj. Studii. Cercetari Chim., 11, 325(1960).

6) 杉田実男, 日化, 88, 659(1967).

7）杉田実男，日化，88，1235(1967)。

8）前報(第 8 報)，杉田実男，日化，88，1237(1967)。 